\title{
JOHN MILLER
}

John Miller, for many years Professor of Mathematics in the Royal Technical College, Glasgow, was born in Glasgow in 1871 and was the eldest of six sons, all of whom were graduates of the University of Glasgow and had distinguished careers in their various spheres of activity. He was educated at John Street School, the Free Church Training College for Teachers and at the University where, after winning prizes in the classes of Latin, Greek, Mathematics and Natural Philosophy, he graduated M.A. with First Class Honours in Mathematics and Natural Philosophy in 1896 . He continued his studies in Mathematics (he had a special interest in Geometry) and subsequently spent a summer doing advanced work at Göttingen.

After a very short period of school teaching in Maybole, Miller was appointed in 1897 to a George A. Clark scholarship in the University, where he was then obliged to conduct tutorial classes both in Mathematics and in Natural Philosophy. In 1899 he was appointed Assistant to George A. Gibson, Professor of Mathematics in the Glasgow and West of Scotland Technical College (later known as the Royal Technical College, Glasgow, and now known as the Royal College of Science and Technology, Glasgow), and in 1909, when Gibson moved to the University, succeeded him in the chair. In the same year he was awarded the degree of D.Sc. for a thesis dealing with the geometry of the triangle and the conic sections.

Miller remained in the Technical College, where he was held in high regard as a clear, concise and methodical lecturer, until 1934, when he retired at the age of 63 . He retired before the usual age in order to be able to extend his study of the Classics, for which he had a deep and abiding love, and to visit some of the places of importance in Latin and Greek lore.

Miller died on 14th July 1956, having been predeceased by his wife in 1928. There were no children of the marriage. 